\title{
Three Times Monthly
}

National Cancer Institute

\section{Source}

National Cancer Institute. Three Times Monthly. NCI Thesaurus. Code C98859.

Three times per month. 